\title{
Serebral Palsili Çocukların ve Annelerin Uyku Kalitesini ve Annelerdeki Depresyonu Etkileyen Faktörler
}

Factors Effecting Sleep Quality of Children with Cerebral Palsy and Mother and Depression in Mother

Vildan Binay SAFER ${ }^{1}$

1. Sağlık Bilimleri Üniversitesi, Sultan Abdülhamid Han Eğitim ve Araştırma Hastanesi, Istanbul

\section{$\ddot{O Z E T}$}

Amaç: Serebral palsili (SP) çocukların annelerinde depresyon ve uykuyu değerlendirmek ve bu parametrelerin SP'li çocuğun uyku bozukluğu ile ilişsisini araştırmak.

Gereç ve Yöntemler: SP'li çocukların karakteristik özellikleri, çocukların fonksiyonel seviyeleri (Kaba Motor Fonksiyon Siniflama Sistemi) ve spastisite düzeyleri (Modifye Ashworth Skalası) kaydedildi. Çocuk Uyku Alışkanlıkları Anketi skorları, annelerin Pittsburgh Uyku Kalite Indeksi ve Beck Depresyon Ölçeği II skorlart incelendi.

Bulgular: Annelerin bekar olması ile Pittsburgh uyku kalite indeksi $(5,61 \pm 0,46 / 10,00 \pm 2,52 ; p=0,05)$, Beck depresyon ölçeği II (p: 9,03 $\pm 1,39 / 26,33 \pm 7,22 ; p=0,05$ ) ve Çocuk uyku alışkanlıkları anketi $(46,73 \pm 1,11 / 54,33 \pm 2,18 ; p=0,02)$ arasinda istatistiksel olarak anlaml ilișki saptandl. Pittsburgh Uyku Kalite İndeksi skorlart ile Beck Depresyon Ölçeği II $(r=0,51, p=0,02)$ ve Çocuk Uyku Allşkanlıklarl Anketi skorlarl $(r=0,45, p<0,01)$ arasinda da anlamlı korelasyon saptandı. Benzer şekilde Beck Depresyon Ölçeği II ile Çocuk Uyku Alışkanlıkları Anketi skorları arasında ( $r=$ $0,43, p=0.01$ ) orta düzey korelasyon saptandl.

Sonuç: Mevcut sonuçlar SP'li çocuk ile annenin uyku bozukluğunun ilişkisini göstermekte ve bunun muhtemel bir sonucu olarak annede depresyon gelişimine yatkınlık oluşturduğunu düsündürmektedir. Sadece SP'li çocukların uyku bozuklukları değil annelerin de uyku ve depresyon problemlerinin rutin olarak takip edilmesi gerektiğini bu sonuçlar ortaya koymaktadır.

Anahtar Kelimeler: serebral palsi; uyku bozukluğu; depresyon; anne

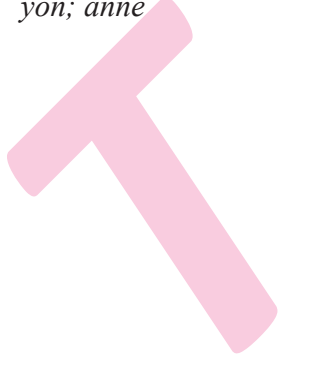

Iletişim Bilgileri

Sorumlu Yazar: Vildan Binay SAFER

Yazışma Adresi: Sağlık Bilimleri Üniversitesi, Sultan Abdülhamid Han Eğitim ve Araştırma Hastanesi, İstanbul

E-posta: binayvildan@gmail.com

Tel: +90 (216) 5422020 - 3855

Makale Geliş Tarihi: 04.02.2017

Makale Kabul Tarihi: 15.03.2017

DOI: http://dx.doi.org/10.16948/??????

\section{ABSTRACT}

Objective: Aim of this study is to evaluate depression and sleep quality in mothers with children with cerebral palsy and to investigate relationships between these parameters and sleep problems children with cerebral palsy.

Material and Methods: Characteristic features of children with cerebral palsy, functional levels (gross motor function classification system), spasticity (Modified Ashworth Scale) were determined. The Children's Sleep Habits Questionnaire and Pittsburgh Sleep Quality Index and Beck Depression Inventory II of mothers were evaluated.

Results: Statistical significant relationship between single mothers and Pittsburgh Sleep Quality Index (5,61 $\pm 0,46 / 10,00$ $\pm 2,52 ; p=0,05)$, $(p: 9,03 \pm 1,39 / 26,33 \pm 7,22 ; p=0,05)$, Beck Depression Inventory II and The Children's Sleep Habits Questionnaire $(46,73 \pm 1,11 / 54,33 \pm 2,18 ; p=0,02)$ were observed. Also, significant correlations between Pittsburgh Sleep Quality Index and Beck Depression Inventory II $(r=0,51, p=0,02)$, and The Children's Sleep Habits Questionnaire $(r=0,45, p<0,01)$ were observed. Similarly, moderate significant correlation was observed between Beck Depression Inventory II and The Children's Sleep Habits Questionnaire.

Conclusion: Our results indicated relationship between sleep problems of children with cerebral palsy and mothers and as a consequences of this relationship predisposition to the depression in mother might be possible. Also, our results showed that not only sleep problems children with cerebral palsy, but also sleep and depression mood of mother should be routinely assessed in mothers.

Keywords: cerebral palsy; sleep problem; depression; mother 


\section{GIIRIȘ}

Serebral palsi (SP) immatür beynin ilerleyici olmayan hasarından kaynaklanan hareket ve postür gelişiminin bir grup bozukluğu olup, çocukluk çağının en sık görülen özürlülük nedenlerinden biridir (1). SP prevalansı gelişmekte olan ülkelerde ortalama olarak 1000 canlı doğumda 1,7- 2 olarak bildirilmiştir (2). Türkiye'de SP prevalansının 1000 canlı doğumda 4,4 olduğunu bildiren çalışmalar mevcuttur (3).

SP'nin ana bileşeni her ne kadar motor fonksiyon bozukluğu olsa da siklıkla duyusal, konuşma ve dil bozuklukları, işitsel ,görsel , davranıșsal ve öğrenme problemleri, epilepsi ve uyku bozuklukları gibi birçok problem de eşlik eder (4). SP'li çocuklardaki hareket bozukluğu ve buna eşlik eden hareket bozukluğu dışındaki problemler hastanın ve hastaya sürekli bakım veren kişinin (sıklıkla annenin) yaşam kalitesini etkilemektedir (5). Çocuğun bakıma ihtiyaç duyması ve ek problemleri nedeniyle bakım veren kişi duygu durum bozukluğu ve tükenmişlik açısından risk altında olup bakıcı yükünü etkileyen önemli faktörlerden biri de çocuğun uyku düzenidir (6).

SP'li çocuklardaki uyku problemleri, normal gelişim gösteren çocuklara oranla 4 kat daha sık gözlenmektedir. Aynı zamanda bakım veren kişinin uyku kalitesinin çocuğun uyku bozukluğu ile korele olduğu gösterilmiş olup bakım verenin depresyonu ile de nedensel bir ilişkisi olabileceği düşünülmüsşür (7).

Hemmingsson ve ark. SP'li çocukların \% 39,8 'inin her gece en az bir kez bakım verene ihtiyaç duyduğu ve bu durumun bakım verenin gündüz aktivitelerini olumsuz etkilediğini göstermiştir (8).

SP'li çocuğa bakım verenin ruhsal süreçlerinin, çocukların yaşam kalitelerini etkilediği gösterilmiştir (9). Bu çalışmada SP'li çocuğa sürekli bakım veren kişide (anne) depresyon ve uyku bozukluğunu ve SP'li çocuğun uyku bozukluğu ile ilişki faktörlerini araştırmayı amaçladik.

\section{GEREÇ ve YÖNTEM}

Bu çalıșma Sağlık Bakanlığ Tedavi ve Rehabilitasyon Eğitim ve Araştırma Hastanesi'nde, hastanenin lokal etik kurul onayı alınarak gerçekleştirildi. Çalışmaya daha önce SP tanısı almış 36 çocuk ve anneleri alınd1. Annelere sözlü ve yazılı bilgilendirme yap1larak "Onam Formu"nu imzalayan gönüllüler çalışmaya dahil edildi.
Çocukların ve annelerinin demografik verileri kaydedildi. Çocukların fonksiyonel seviyesi Kaba Motor Fonksiyon Sinıflama Sistemi (KMFSS) ile spastisite düzeyi Modifiye Ashworth Skalası (MAS) ile değerlendirildi.

\section{Çalışmaya alınma kriterleri:}

1. SP tanısı almış 3-14 yaş arası çocuklar

2. Sürekli bakım verenin, çocuğun annesi olması

3. MAS'a göre evre 2 veya üzeri olanlar

\section{Dışlanma kriterleri:}

1. Son 6 ayda ilaç değişikliği, cerrahi veya botulinum toksin öyküsü olan çocuklar

2. Annenin depresyon nedeni ile antidepresan kullanımı, psikoterapi vb alıyor olması

\section{3. Özürlü bir kardeşin daha olması}

4. Anne tarafından gönüllü onam formunun imzalanmamış olması.

SP'li çocuğun demografik verileri, uyku problemiyle ilişkili olabilecek faktörler (epilepsi, görme bozuklukları, entellektüel bozukluk), ilaç öyküsü, gece ortez kullanımı, standart fizik muayene bulguları, vücut ağırlıkları $(\mathrm{kg})$, KMFSS seviyesi ve spastisite için MAS seviyesi kaydedildi. SP'li çocukların anneleri için demografik veriler kaydedildi.

\section{Değerlendirmeler:}

Çocuklarda spastisiteyi değerlendirmek için MAS, fonksiyonel seviyeyi değerlendirmek için KMFSS kullanıldı.

Annenin son 1 aydaki uyku kalitesini ve uyku bozukluğunu değerlendirmek için Pittsburgh Uyku Kalite İndeksi kullanıldı. Pittsburgh Uyku Kalite İndeksi'nin Türkçe geçerlilik ve güvenirliği Ağargün ve arkadaşları tarafından yapılmış olup hastada hem uyku kalitesini, hem de gündüz uykululuğu ile ilgili bir sorun olup olmadığını değerlendirmektedir. Subjektif uyku kalitesi, uykuya geçme süresi, uyku süresi, uyku effektivitesi, uykuyu etkileyen durumlar, uyku verici madde kullanımı ve gün içinde uyuklamanın değerlendirildiği 7 bölüm ve toplam 18 maddeden oluşmaktadır.

Yüksek puanlar uyku kalitesinin bozuk olduğunu göstermekte olup toplam skorun 5'in üstünde olması uyku kalitesinin bozulduğunu gösterir (10). 
Annedeki depresyonun varlığı ve şiddetini değerlendirmek için Beck Depresyon Ölçeği II (BDÖ-II) kullanıldı. Ölçeğin ülkemizde geçerlilik ve güvenilirlik çalışması, Kapcı ve arkadaşları tarafından yapılmıştır. Ölçek 21 maddeden oluşan kendini değerlendirme ölçeğidir. Her madde 0-3 arasinda puanlanır.

Toplampuanınyüksekolmasıdepresyonşiddetinin yüksekliğini gösterir. Toplam skor 0-12 ise minimal depresyonu, 13-18 ise hafif düzeyde depresyonu, 19-28 ise orta düzeyde depresyonu ve 29-63 ise şiddetli depresyonu gösterir (11).

SP'li çocuğun uyku kalitesini değerlendirmek için çocukların uyku alışkanlıklarını ve uyku ile ilişkili sorunlarını araștırmaya yönelik olarak 2000 yılında Owens ve arkadaşları tarafından geliştirilen Çocuk Uyku Alışkanlıkları Anketi-kısa formu kullanıldı (12). Fiş ve ark. tarafından Türkçe geçerliliği ve güvenilirliği yapılmış olan anket toplam 33 maddeden oluşmaktadır. Ölçekte yatma zamanı direnci, uykuya dalmanın gecikmesi, uyku süresi, uyku kayg1s1, gece uyanmaları, para-somniler, uykuda solunumun bozulması ve gün içinde uykululuk şeklinde sıralanabilen sekiz alt ölçek tanımlanmıştır. Toplamda elde edilen 41 puan kesim noktası olarak kabul edilmekte ve bunun üzerindeki değerler 'klinik düzeyde anlamlı uyku bozukluğu' olarak değerlendirilmektedir (13).

\section{ISTATISTIKSEL ANALIZ}

Çalışmada elde edilen bulgular değerlendirilirken, istatistiksel analizler için SPSS 20.0 software (SPSS, Inc., Chicago, IL, USA) programı kullanıldı. Ölçümle belirlenen değişkenler için ortalama \pm standart sapma, sayımla belirlenen değişkenler için yüzde (\%) değeri hesapland1. Çalışmamızda elde edilen veriler normal dağılım özelliği Shapiro-Wilk testi ile değerlendirildi. Aynı değişkenin farklı iki gruptaki ortalamaları arasındaki farkın testi için Mann Whitney U Test'ten ve Student's T Test'ten faydalanıldı. Sayısal değişkenler arasındaki ilişki Spearman korelasyon katsayısı ile değerlendirildi. Anlamlılık düzeyi $\mathrm{p}<0.05$ olarak alındı.

\section{BULGULAR}

Çalışmaya alınan 36 SP'li çocuğun \%50'si $(n=18)$ erkek, \%50'si $(n=18)$ kızdı. Çocukların yaş ortalaması $7,15 \pm 2,5$, annelerinki ise $34,7 \pm$ 9,7 yıl idi. Çocukların KMFSS'ne göre seviyeleri $\% 5,6$ 's1 seviye $1, \% 13,9$ 'u seviye $2, \% 36,1$ 'i seviye 3, \%33,3'ü seviye 4, \%11,1'i seviye 5'ti. Çocukların ve annelerin diğer demografik verileri Tablo 1'de, çocukların KMFSS seviyeleri Şekil 1'de, MAS değerleri Şekil 2'de gösterildi.
Anneler medenî durumlarına göre değerlendirildiğinde Pittsburgh Uyku Kalite Indeksi (evli/bekâr; p: 5,61 \pm 0,46/ 10,00 \pm 2,52; p=0,05), BDÖ-II (evli/bekâr; p: 9,03 \pm $1,39 / 26,33 \pm 7,22 ; \mathrm{p}=0,05)$ ve Çocuk Uyku Alışkanlıkları Anketi (evli/bekâr; p: 46,73 \pm $1,11 / 54,33 \pm 2,18 ; p=0,02)$ yönünden karşılaşt1rıldığında istatistiksel olarak anlamlı fark oldu$\breve{g u}$ tespit edildi. Çocuklar kognitif durumlarına göre değerlendirildiğinde, Pittsburgh Uyku Kalite İndeksi (kognitif bozukluk var/kognitif bozukluk yok; $p: 8,5 \pm 1,18 / 5,47 \pm 0,51 ; p=0,02)$; gayta inkontinansına göre değerlendirildiğinde, BDÖ-II'nde (gayta inkontinansı var/ gayta inkontinans1 yok; p: 14,69 $\pm 2,51 / 7,10 \pm 1,74$; $\mathrm{p}=0,02)$ istatistiksel olarak anlamlı fark tespit edildi (Tablo 2).

BDÖ-II ile Pittsburgh Uyku Kalite İndeksi skorları arasinda $(\mathrm{r}=0,51, \mathrm{p}=0,02)$ orta düzey pozitif anlamlı korelasyon saptand. Benzer şekilde BDÖ-II ile Çocuk Uyku Alışkanlıkları Anketi skorları $(\mathrm{r}=0,43, \mathrm{p}=0.01)$ ve Pittsburgh Uyku Kalite İndeksi skorları ile Çocuk Uyku Alışkanlıkları Anketi arasında $(\mathrm{r}=0,45, \mathrm{p}<0,01)$ orta düzey anlamlı korelasyon saptandı (Tablo 3). Çocukların fonksiyonel seviyeleri ve spastisite düzeyleri ile Pittsburgh Uyku Kalite İndeksi, BDÖ-II ve Çocuk Uyku Alışkanlıkları Anketi skorları arasında anlamlı korelasyon saptanmad1 (Tablo 4).

\begin{tabular}{|c|c|}
\hline \multicolumn{2}{|l|}{ Annelerin karekteristik özellikleri } \\
\hline Yaş, ortalama \pm SD, yıl & $34,7 \pm 9,7$ \\
\hline Eğitim yılı ortalama $\pm \mathrm{SD}$ & $6,1 \pm 3,1$ \\
\hline Eğitim Düzeyi (Ortaokul ve altı/Lise ve üzeri & $24 / 12$ \\
\hline Medeni hal Evli \% (n) & $91.7(33)$ \\
\hline \multicolumn{2}{|c|}{ Serebral palsili çocukların karekteristik özellikleri } \\
\hline Yaş, ortalama \pm SD, yıl & $7,15 \pm 2,5$ \\
\hline Vücut ağırlığı, ortalama \pm SD, kg & $23,66 \pm 9,27$ \\
\hline Cinsiyet Erkek/Kız \% (n) & $50(18) / 50(18)$ \\
\hline \multicolumn{2}{|l|}{ Gestasyon } \\
\hline Preterm \% (n) & $55,6(20)$ \\
\hline Term \% (n) & $44,4(16)$ \\
\hline İşitme Bozukluğu \% (n) & $8,3(3)$ \\
\hline Görme Bozukluğu \% (n) & $19,4(7)$ \\
\hline Kognitif bozukluk \% (n) & $16,7(6)$ \\
\hline Epilepsi \% (n) & $30,6(11)$ \\
\hline Üriner inkontinans \% (n) & $16(44,4)$ \\
\hline Fekal inkontinans \% (n) & $16(44,4)$ \\
\hline Gece Splinti kullanımı \% (n) & $22,2(8)$ \\
\hline
\end{tabular}


Tablo 2: Bireylerin karekteristik özellikleri ile Pittsburgh uyku kalite indeksi (Anne), Beck depresyon ölçeği (Anne) ve Çocuk uyku alışkanlıkları anketi skorlarının karşılaştırıması.

\begin{tabular}{|c|c|c|c|c|c|c|c|c|}
\hline & & & \multicolumn{2}{|c|}{$\begin{array}{l}\text { Pittsburgh uyku kalite } \\
\text { indeksi (Anne) }\end{array}$} & \multicolumn{2}{|c|}{$\begin{array}{l}\text { Beck depresyon ölçeği } \\
\text { (Anne) }\end{array}$} & \multicolumn{2}{|c|}{$\begin{array}{c}\text { Çocuk uyku } \\
\text { alışkanlıkları anketi }\end{array}$} \\
\hline & & & $\begin{array}{l}\text { Ortalama } \\
\quad \pm \text { SS }\end{array}$ & $\mathrm{p}$ & $\begin{array}{l}\text { Ortalama } \\
\quad \pm \text { SS }\end{array}$ & $\mathrm{p}$ & $\begin{array}{l}\text { Ortalama } \\
\quad \pm \text { SS }\end{array}$ & $\mathrm{p}$ \\
\hline \multirow{4}{*}{ 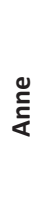 } & \multirow{2}{*}{ Medeni Hal } & Evli $(n=33)$ & $5,61 \pm 0,46$ & \multirow{2}{*}{$0,05^{*}$} & $26,33 \pm 7,22$ & \multirow{2}{*}{$0,05^{*}$} & $46,73 \pm 1,11$ & \multirow{2}{*}{$0,02 *$} \\
\hline & & Bekâr (n=3) & $10,00 \pm 2,52$ & & $9,03 \pm 1,39$ & & $54,33 \pm 2,18$ & \\
\hline & \multirow{2}{*}{ Eğitim Durumu } & Ortaokul ve öncesi $(n=24)$ & $6,04 \pm 0,55$ & \multirow{2}{*}{0,30} & $10,79 \pm 2,02$ & \multirow{2}{*}{0,78} & $46,50 \pm 1,26$ & \multirow{2}{*}{0,79} \\
\hline & & Lise ve sonrası $(n=12)$ & $5,83 \pm 1,06$ & & $9,83 \pm 2,65$ & & $49,08 \pm 2,05$ & \\
\hline \multirow{17}{*}{ 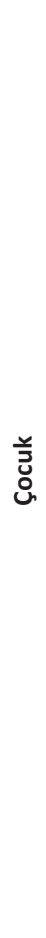 } & \multirow{2}{*}{ Gestasyon } & Preterm $(n=20)$ & $5,60 \pm 0,7$ & \multirow{2}{*}{$0,49 *$} & $8,95 \pm 1,61$ & \multirow{2}{*}{$0,29 *$} & $46,55 \pm 1,58$ & \multirow{2}{*}{$0,33^{*}$} \\
\hline & & Term $(n=16)$ & $6,53 \pm 0,76$ & & $11,27 \pm 2,92$ & & $47,87 \pm 1,46$ & \\
\hline & \multirow{2}{*}{ İşitme Problemi } & $\operatorname{Var}(n=3)$ & $4,67 \pm 0,33$ & \multirow{2}{*}{$0,48^{*}$} & $5,00 \pm 3,51$ & \multirow{2}{*}{$0,22^{*}$} & $43,33 \pm 2,91$ & \multirow{2}{*}{$0,29 *$} \\
\hline & & Yok $(n=33)$ & $6,09 \pm 0,54$ & & $10,97 \pm 1,69$ & & & \\
\hline & \multirow{2}{*}{ Görme Problemi } & $\operatorname{Var}(n=7)$ & $6,29 \pm 0,75$ & \multirow{2}{*}{$0,50 *$} & $6,14 \pm 1,55$ & \multirow{2}{*}{$0,22^{*}$} & $47,43 \pm 1,73$ & \multirow{2}{*}{$0,90 *$} \\
\hline & & Yok $(n=29)$ & $5,90 \pm 0,6$ & & $11,52 \pm 1,89$ & & $47,34 \pm 1,29$ & \\
\hline & \multirow{2}{*}{ Kognitif Bozukluk } & $\operatorname{Var}(n=6)$ & $8,5 \pm 1,18$ & \multirow{2}{*}{$0,02 *$} & $13,33 \pm 5,02$ & \multirow{2}{*}{$0,42 * *$} & $49,50 \pm 1,80$ & \multirow{2}{*}{$0,39 *$} \\
\hline & & Yok $(n=30)$ & $5,47 \pm 0,51$ & & $9,90 \pm 1,65$ & & $46,93 \pm 1,25$ & \\
\hline & \multirow{2}{*}{ Epilepsi } & $\operatorname{Var}(n=11)$ & $5,44 \pm 0,57$ & \multirow{2}{*}{$0,06 *$} & $12,09 \pm 2,89$ & \multirow{2}{*}{$0,50 * *$} & $48,82 \pm 1,82$ & \multirow{2}{*}{$0,35^{*}$} \\
\hline & & Yok $(n=19)$ & $3,28 \pm 0,83$ & & $9,76 \pm 1,92$ & & $46,72 \pm 1,34$ & \\
\hline & & $\operatorname{Var}(n=16)$ & $6,47 \pm 0,85$ & & $13,40 \pm 2,53$ & & $48,67 \pm 1,66$ & \\
\hline & İdrar İnkontinansı & Yok $(n=20)$ & $5,62 \pm 0,6$ & $0,32 *$ & $8,38 \pm 1,96$ & $0,12 * *$ & $46,43 \pm 1,44$ & $0,31^{*}$ \\
\hline & & Yok $(n=21)$ & $5,44 \pm 1,33$ & & $10,56 \pm 3,25$ & & $46,78 \pm 2,43$ & \\
\hline & & $\operatorname{Var}(n=16)$ & $6,44 \pm 0,8$ & & $14,69 \pm 2,51$ & & $49,25 \pm 1,6$ & \\
\hline & Gaita Inkontinansı & Yok $(n=31)$ & $5,60 \pm 0,65$ & $0,27^{*}$ & $7,10 \pm 1,74$ & $0,02^{* *}$ & $45,85 \pm 1,43$ & $0,11^{*}$ \\
\hline & & $\operatorname{Var}(n=8)$ & $6,11 \pm 0,58$ & & $6,75 \pm 1,62$ & & $48,18 \pm 1,19$ & \\
\hline & Gece splınti kullanımı & Yok $(n=28)$ & $5,50 \pm 1,01$ & $0,80^{2}$ & $11,54 \pm 1,95$ & $0,18^{\top}$ & $44,50 \pm 2,44$ & $0,32^{*}$ \\
\hline
\end{tabular}

*Mann- Whitney U, **Student'in t dağılımı, SS: Standart sapma.

Tablo 3: Beck depresyon ölçeği (Anne), Pittsburgh uyku kalite indeksi (Anne) ve Çocuk uyku alışkanlıkları anketi arakında korelasyon analizi.

\begin{tabular}{|l|c|c|c|}
\hline \multirow{2}{*}{} & Beck depresyon ölçeği (Anne) & \multicolumn{2}{|c|}{ Pittsburgh uyku kalite indeksi (Anne) } \\
\cline { 2 - 4 } & $\mathrm{p}$ & $\mathrm{p}$ & $\mathrm{p}$ \\
\hline Çocuk uyku alışkanlıkları anketi & 0,43 & 0,01 & 0,45 \\
\hline Pittsburgh uyku kalite indeksi (Anne) & 0,51 & 0,02 & \\
\hline
\end{tabular}

Tablo 4: Çocuk motor fonksiyon ve spastisite düzeyi ile çocuk ve annesin uyku skoru ve anne depresyon ölçek skorunun korelasyon analizi.

\begin{tabular}{|c|c|c|c|c|c|c|c|}
\hline \multicolumn{2}{|l|}{ Spearman korelasyon analizi } & \multicolumn{2}{|c|}{$\begin{array}{l}\text { Pittsburgh uyku kalite } \\
\text { indeksi (Anne) }\end{array}$} & \multicolumn{2}{|c|}{$\begin{array}{c}\text { Beck depresyon ölçeği } \\
\text { (Anne) }\end{array}$} & \multicolumn{2}{|c|}{$\begin{array}{c}\text { Çocuk } \\
\text { uyku alışkanlıkları anketi }\end{array}$} \\
\hline & & $r$ & $p$ & $r$ & $\mathrm{p}$ & $r$ & $p$ \\
\hline \multicolumn{2}{|c|}{ Kaba Motor Fonksiyon Sınıflama Sistemi } & 0,05 & 0,66 & 0,135 & 0,30 & 0,17 & 0,18 \\
\hline \multirow{5}{*}{ Modifiye Ashworth Sınıflaması } & Elbileği & 0,04 & 0,76 & 0,042 & 0,75 & 0,14 & 0,27 \\
\hline & Dirsek & $-0,04$ & 0,73 & $-0,026$ & 0,84 & 0,12 & 0,37 \\
\hline & Kalça & 0,00 & 0,97 & $-0,153$ & 0,24 & 0,12 & 0,32 \\
\hline & Diz & $-0,06$ & 0,63 & $-0,035$ & 0,79 & 0,03 & 0,78 \\
\hline & Ayakbileği & 0,10 & 0,48 & $-0,007$ & 0,95 & 0,06 & 0,66 \\
\hline
\end{tabular}



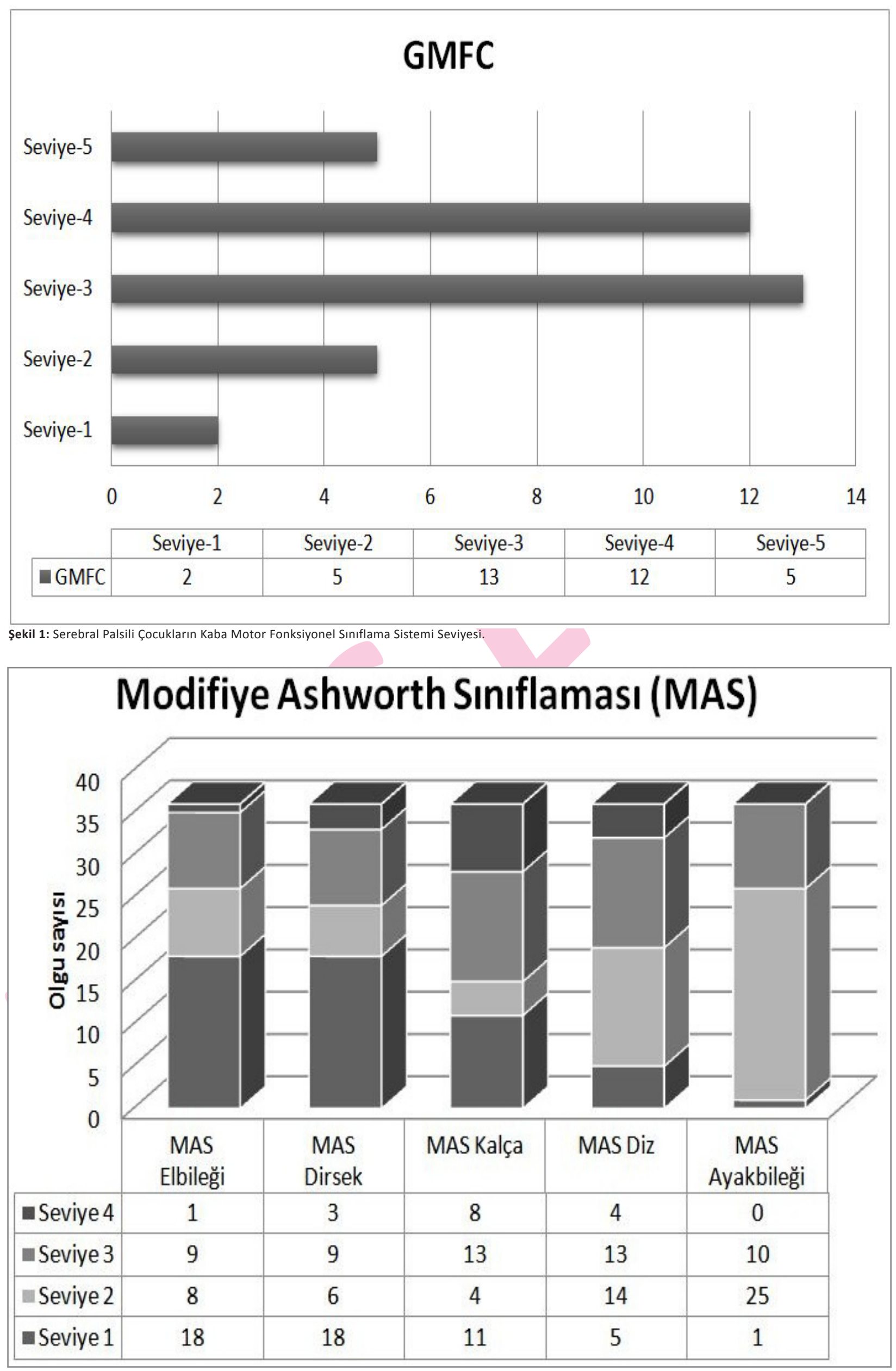


\section{TARTIŞMA}

SP'li çocuğa sürekli bakım veren kişide depresyon ve uyku bozukluğunu ve SP'li çocuğun uyku bozukluğu ile ilişki faktörlerinİ araştırmayı amaçlayan bu çalışmada; annelerin medeni durumlar1 ile Pittsburgh Uyku Kalite İndeksi, BDÖ-II ve Çocuk Uyku Alışkanlıkları Anketi sonuçları arasında istatistiksel olarak anlamlı ilișki saptandı.Cocukların kognitif durumları ile Pittsburgh Uyku Kalite İndeksi; gayta inkontinansı durumları ile de, BDÖ-II ölçeği arasında istatistiksel olarak anlamlı ilişki saptand. Çocukların KMFSS seviyeleri ve MAS düzeyleri ile çocuk uyku bozukluğu ve annelerin depresyon ve uyku bozukluğu arasında anlamlı ilișki saptanmaz iken Pittsburgh Uyku Kalite İndeksi, BDÖ-II ve Çocuk Uyku Alıșkanlıkları Anketi sonuçları arasında orta düzeyde anlamlı korelasyon gözlendi. SP'li bir çocuğa sahip olmak, ebeveynlerde tükenmişlik gelişmesi için önemli bir risk faktörüdür. Anneler, SP'li çocuğun temel ihtiyaçlarının karşılanmasını ve rehabilitasyon sürecini sıklıkla üstlenmektedir. Buna bağlı olarak annelerde depresyon gelișme riski yüksektir. Akmeşe ve ark. rehabilitasyon programındaki çocukları değerlendirdiği çalışmada SP'li çocukların annelerinde depresyon \%60 oranında gözlenirken, normal gelişim gösteren çocukların annelerinde bu oran \%41,1 olarak saptanmıştır (14). Benzer şekilde Unsal-Delialioglu ve ark. da, SP' li çocukların annelerinde anlamlı düzeyde daha fazla depresyon bildirmistir (15).

Çocuğun vücut yapı ve fonksiyonlarındaki bozukluk ve SP'ye bağlı engellilik düzeyinde artış ile annelerdeki depresyon riskinde artış öngörülmesi makul gözükmektedir. Ancak bizim çalışmamızda, SP'li çocuğun KMFSS seviyesi ile annenin depresyon düzeyi arasında ilişki saptanmamıştır. Geniş katılımlı bir çalışmada, SP'li çocukların annelerinde psikolojik durumu etkileyen faktörler arasında çocuğun bakım ihtiyacı düzeyi, çocuktaki davranıș bozuklulukları ve ailenin özellikle sosyal katılımında kısıtlanmasının yer aldığı bildirilmiştir (6). Mutlu ve ark. SP'li çocukların özür düzeyleri ve spastisite düzeylerinin annelerin depresyon düzeylerini etkilediğini bildirmiştir (16). Bununla birlikte Wayte ark, Unsal-Deliaoglu ve ark. ve Önes ve ark. çalışmalarında çocukta spastisite ve fonksiyonel seviye ile annenin depresyonu arasinda anlaml bir ilişki saptanmamıştır $(15,17,18)$. Zihinsel ve/veya bedensel özürlü çocukların değerlendirildiği, Şenveli ve ark.nın çalışmasında annelerin depresyon düzeylerinde anlamlı bir farkl1lık bildirilmemiștir (19). Bu çalışmada KMFSS ve MAS seviyeleri ile annelerin depresyon ve uyku bozukluğu arasında anlamlı ilişki saptanmamıştır. Ayrıca, gaita inkontinansı olan çocukların annelerinde depresyonun daha fazla saptanmas1 çocukların bakım ihtiyacının artışının anne depresyonunda önemli bir faktör olduğunu göstermektedir. SP'li çocuklardaki uyku bozukluğu, normal gelişim gösteren çocuklara göre daha yüksek oranda bildirilmektedir. Bu çalışmalarda, en az bir uyku parametresinde bozukluğu saptanma oranı $\% 33$ ile $\% 48$ arasında değișen oranlarda bildirilmiştir $(7,8,20,21)$. Bu çalışmadaki SP'li çocuklardaki uyku bozukluğu oranı \%75'idi. Çocuk Uyku Alışkanlıkları Anketi sonuçları sadece bekâr anne grubunda anlamlı olarak yüksek saptanmıştır. Wayte ve ark. çalışmasında çocuklardaki uyku bozukluğu çocuğun görme bozukluğu ile ilişkili saptanırken, bu çalışmamızda bu yönde ilişki gözlenmemiştir (5). Uyku bozukluğunun bu çalışma grubunda yüksek olması merkezimizin ülkemizde referans merkez olmas1, buna bağlı olarak örneklemin çoklu problemi daha fazla olan SP'li olgulardan oluşmasından kaynaklanmış olabileceğini düşündürmektedir. Bu çalışmada, Pittsburgh Uyku Kalite İndeksi, BDỎ-II ve Çocuk Uyku Alışkanlıkları Anketi sonuçları arasında orta düzeyde anlamlı korelasyon saptanması; çocuğun uyku problemlerinin, primer bakım veren durumundaki annenin uyku problemleri yaşamasına, bunun sonucu olarak tükenmişlik gelişmesine ve annede depresyon gelişimine neden olduğunu düşündürmektedir. Bununla birlikte bu çalışmanın kesitsel çalışma olması bu direkt ilişkinin net olarak kurulmasını kısıtlamaktadır. SP'li çocuklarda yapılan diğer çalışmalarda bizim sonucumuzu destekler niteliktedir. Wayte ve ark. çalışmasında annenin ve SP'li çocuğun uykularının benzer şekilde anlam11 ilişki olduğunu gösterilmiştir (5). Ancak, Wayte ark. bu iki parametre arasında ilişkiyi düşük düzeyde korele rapor ederken bu çalışmamızda orta düzey bir korelasyon saptanmıştır. Çalışmamızın kesitsel dizaynda olması, uyku bozuklugunun ve depresyon durumunun altın standart yöntemler yerine geçerliliği ve güvenirliği gösterilmiş anketler ile değerlendirilmesi kısıtlllıkları arasındadır. Bununla birlikte tüm anket incelenmesinin tek bir fiziksel tip ve rehabilitasyon uzmanı gözetiminde uygulanması; anketin çoklu kişiler tarafindan uygulanmasından kaynaklanabilecek karıştırıcı etkinin önlenmesi yönünden önemlidir.

Mevcut sonuçlar SP'li çocuğun ve annenin uyku bozukluğunun ilişkisini göstermekte ve bunun muhtemel bir sonucu olarak annede depresyon gelişimine yatkınlık oluşturduğunu düşündürmektedir. Dolayısıyla sadece SP'li çocukların değil, annelerinin de uyku ve duygudurum bozukluklarının rutin olarak takip edilmesi gerektiğini bu sonuçlar ortaya koymaktadır. Ek olarak, nedensel ilişkinin net olarak ortaya konması için ileri çalışmalara ihtiyaç duyulmaktadır. 


\section{K $A$ Y N A KLAR}

1. Bax M, Goldstein M, Rosenbaum P, Leviton A, Paneth N, Dan B, et al. Proposed definition and classification of cerebral palsy. Dev Med Child Neurol 2005; 47: 571-6.

2. Winter S, Autry A, Boyle C, Yeargin-Allsopp M. Trends in the prevalence of $C P$ in a population-based study. Pediatrics 2002, 110: $1220-5$

3. Serdaroğlu A, Cansu A, Ozkan S, Tezcan S. Prevalence of Cerebral Palsy in Turkish Children Between The Ages of 2 and 16 Years. Dev Med Child Neurol 2006; 48: 413-6.

4. Else Odding, Marij E. Roebroeck, Hendrik J. Stam (2006) The epidemiology of cerebral palsy: Incidence, impairments and risk factors, Disability and Rehabilitation 2006; 28:4, 18391 .

5. Wayte S, McCaughey E, Holley S, Annaz D, Hill CM. Sleep problems in children with cerebral palsy and their relationship with maternal sleep and depression. Acta Paediatr. 2012; 101 (6): $618-23$

6. Raina P, O'Donnell M, Rosenbaum P, Brehaut J, Walter SD, Russell D, et al. The health and well-being of caregivers of children with cerebral palsy. Pediatrics. 2005;115 (6):e626-36.

7. Newman CJ, O’Regan M, Hensey O. Sleep disorder in children with cerebral palsy. Dev Med Child Neurol 2006; 48. 564-8.

8. Hemmingsson H, Stenhammer AM, Paulsson K. Sleep problems and the need for parental night-time attention in children with physical disabilities. Child Care Health Dev 2008; 35: 89-95.

9. Üneri ÖŞ, Karadavut KI. Parent-reported quality of life of children with cerebral palsy: a preliminary study. Nöropsikiyatri Arşivi-Archives of Neuropsychiatry 2010; 47:127-32.

10. Agargun MY, Kara H, Anlar O. The validity and reliability of the Pittsburgh Sleep Quality Index. Turkish J Psychiatry 1996; 7: 107-15.

11. Kapci EG, Uslu R, Turkcapar H, Karaoglan A. Beck Depression Inventory II: Evaluation of the psychometric properties and cut-off points in a Turkish adult population. Depress Anxiety 2008; 25: 104-10.
12. Owens JA, Spirito A, McGuinn M. The Children's Sleep Habits Questionnaire (CSHQ): psychometric properties of a survey instrument for school-aged children. Sleep 2000; 15: 1043-51.

13. Fiş NP, Arman A, Ay P, Topuzoglu A, Güler AS, Gökçe S et al. Cocuk Uyku Alıskanlıkları Anketinin Türkçe geçerliliği ve güvenilirliği. Anadolu Psikiyatri Dergisi 11 (2):151-60.

14. Akmeşe P, Mutlu A, Öğretmen T, D’Alessandro H. Serebral Palsili ve Sağlıklı Çocukların Annelerinin Depresyon Düzeyleri Arasında Fark Var Mıdır? Sürekli Tıp Eğitimi Dergisi $2015 ; 24$ (3): 83-8.

15. Unsal-Delialioglu S, Kaya K, Ozel S, Gorgulu G. Depression in mothers of children with cerebral palsy and related factors in Turkey: a controlled study. Int J Rehabil Res 2009; 32: 199-204.

16. Mutlu A, Akmese P, Gunel M. "Değişik özür seviyesindeki serebral palsili çocukların annelerinin depresyon düzeyleri farklı midır?". Yeni Tip Dergisi, 2010; 27 (2): 87-92.

17. Wayte S, McCaughey E, Holley S, Annaz D, Hill CM. Sleep problems in children with cerebral palsy and their relationship with maternal sleep and depression. Acta Paediatr. 2012; 101 (6): 618-23.

18. Ones K, Yllmaz E, Çetinkaya B, Çă̆lar N. Assessment of the Quality of Life of mothers of children with cerebral palsy (Primary Caregivers). Neurorehabil Neural Repair 2005; 19: 232-7.

19. Senveli B, Molla S, Abay E, Saltık A. Zihinsel velveya bedensel özürlü çocukların ana-babalarında depresyon ve kaygl. Ulusal Psikiyatri Kongresi, 1992, Kongre Bidiri Özetleri Kitabı, 69

20. Romeo DM, Brogna C, Quintiliani M, Baranello G, Pagliano E, Casalino T et al. Sleep disorders in children with cerebral palsy: neurodevelopmental and behavioral correlates. Sleep Medicine 2014; 15: 213-8.

21. Romeo DM, Brogna C, Musto E, Baranello G, Pagliano $E$, Casalino T et al. Sleep disturbances in preschool age children with cerebral palsy: a questionnaire study. Sleep Medicine 2014; 15: 1089-93.
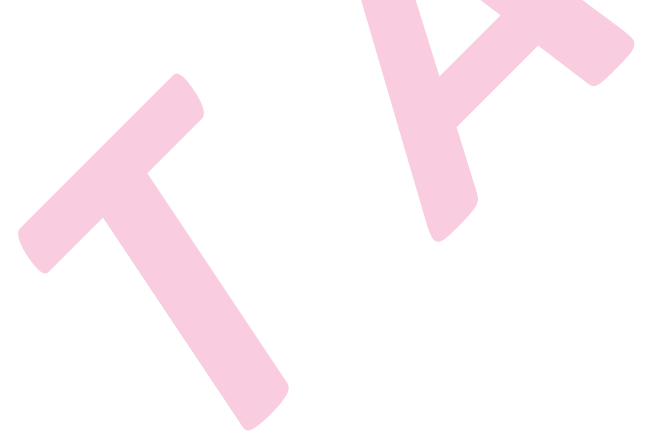